\title{
The Oval
}

Volume 7 | Issue 1

Article 15

2014

Intermediate Disturbance Hypothesis

Gaaby Patterson

Follow this and additional works at: https://scholarworks.umt.edu/oval

Part of the Creative Writing Commons

Let us know how access to this document benefits you.

\section{Recommended Citation}

Patterson, Gaaby (2014) "Intermediate Disturbance Hypothesis," The Oval: Vol. 7 : Iss. 1 , Article 15.

Available at: https://scholarworks.umt.edu/oval/vol7/iss1/15

This Prose is brought to you for free and open access by ScholarWorks at University of Montana. It has been accepted for inclusion in The Oval by an authorized editor of ScholarWorks at University of Montana. For more information, please contact scholarworks@mso.umt.edu. 


\section{Intermediate Disturbance Hypothesis}

\section{Gaaby Patterson}

You know all those dark and damaging things, the things you secret away, pulling them from the pockets of your heart to polish on your sleeve, to look at, to press on like a bruise so they hurt good and remind you of why you've turned out this way.

You know that mother, the overbearing magic one. The one you had to break from in every way, pushing out into the world again and again and again, away from her body, away from that tricky charisma. The one you ripped yourself from, her body, her clutches, her influence, at birth, on that plane when you were eleven years old, again at seventeen, running off with those boys, those drugs, doing whatever you could to become yourself, to burst from the chrysalis, broken wings and all.

You know that dad-or do you? The one who left before you walked in order to start the new family with the new wife, and the new wife, and the new wife, leaving each family in turn, as children got minds of their own, became individuals, made the decision to hate him. The one you predicted-when you were drunk that night at fourteen, with him, that absent father, the only thing on your drunk and perseverating mind-was going to die a lonely old man.

You know that boy, the one who broke you into a thousand pieces a million times, who used your love to satiate his ego. The one you followed into that dingy apartment-you, a willing participant in your own decimation, giving yourself in whole, happy to take scraps.

You know that life, steeped in alcoholism, in disease, in lossthe darkness claiming love after love after love after love after love after love as you stand helpless, a finite speck against the tide, unable to predict, unable to protect, unable to save anyone but yourself.

You know that baby that slipped from your grasp, falling from your family before she even had a chance to know what she was 
leaving.

You know-of course you know - inherent inside, in strange design, that these are the very things! These things you resist, you resent, you think mean pain-turn them on their side!

Quit knowing them as you do.

These are gifts with which you have been entrustedintermediate disturbances that hold your worth and fill your spiritual feet with cement, tethering you to the ground, to yourself, to the earth in earnest. They are the things that make you real and rich and complex. Know these things differently, as offerings placed in your care, the substance and grist of you. 